\title{
The Search for a Result-Oriented Public Sector Reform in Ghana: A Myth or Reality?
}

\author{
Akpeko Agbevade, $\mathrm{PhD}$ \\ Department of Political Science, University of Ghana, Legon \\ Desmond Tweneboah-Koduah, $\mathrm{PhD}$ \\ Department of Political Science, University of Ghana, Legon
}

Received: Apr. 16, 2020 Accepted: Aug. 3, 2020 Online published: Sept.2, 2020

doi:10.5296/jpag.v10i3.17628 URL: https://doi.org/10.5296/jpag.v10i3.17628

\begin{abstract}
The article examined whether public sector reforms in Ghana is a myth or reality. It emerged that since independence in 1957, successive governments implemented both socialist and market-oriented public sector reforms; however, none of these reforms yielded the expected outcome. Hence, the New Patriotic Party on winning political power initiated the National Public Sector Reform Strategy. This reform was aimed at using the public sector as the catalyst to stimulate the private sector for job creation and national development. The study found that the reform made some gains. However, excessive partisanship, narrow political commitment, donor-funding, the time boundedness of the reform and focus on only 16 Ministries, Departments and Agencies militated against its success hence public sector reform is a myth in Ghana. The paper recommends commitment to the directive principles of state policy as the panacea to effectiveness of public sector reforms in Ghana.
\end{abstract}

Keywords: administrative reform, public sector reforms

\section{Introduction}

Since Ghana attained independence in 1957, reforming the administrative state inherited from the British colonial authorities occupied a significant part of her penchant for development. As a result, successive governments, both civilian and military implemented both socialist and market-oriented public sector reforms aimed at achieving efficient, effective and accountable public sector organisations. However, the reforms implemented by the various governments failed to alter the status quo in the public sector (Ayee, 2017; Ohemeng and Ayee, 2016; Ohemeng and Anebo, 2012). Notable among the public sector reforms were: the democratic centralism reform of the Convention Peoples' Party (CPP) in 1957, the Civil 
Service Reform in 1966 by the National Liberation Council (NLC) which was continued by the Progress Party (PP) in 1969, the Reorganisation of the Civil Service by the National Redemption Council (NRC) in 1976; the Civil Service Reform Programme of the Provisional National Defence Council (PNDC) between 1984 and 1992 (Ohemeng and Ayee, 2016, Ohemeng and Anebo, 2012; Antwi et.al. 2008, Ayee, 2001). On return to constitutional rule in 1993, the National Democratic Congress (NDC) implemented the Civil Service Performance Improvement Programme following the passage of the Civil Service Law (1993) Act 327, the New Patriotic Party (NPP) which won the 2000 general elections and governed the country between 2001 and 2008 launched the Public Sector Reform Programme (PSRP) implemented by the Ministry of Public Sector Reform. The NDC upon assuming power in 2009, also introduced the "new approach" to public sector reform aimed at better service delivery (Ohemeng and Ayee, 2016; Ohemeng and Anebo, 2012). However, none of these reforms was able to drastically transform the public sector compelling Quartey (2007) to remark, "whether the Ghana Civil Service is an engine of growth for development or impediment". Similarly, Ohemeng and Ayee (2016) commented that the Civil Service in Ghana is seen as a hindrance because of its intractability. The failure of these hitherto reforms motivated the NPP which won the 2016 general elections to embark on the search for a result-oriented public sector reform, which culminated into the introduction of a National Public Sector Reform Strategy (NPSRS), 2018-2023, with the Public Sector Reform for Results Project (PSRRP) as the supporting tool for implementation. The fundamental objective of this reform is to use the public sector to propel private sector growth, job creation and national development (www.osm.gov.gh)

Against this backcloth, this article sets out to answer the following questions: to what extent were these reforms appropriate for reforming Ghana's public sector? What were the ideological underpinnings of each reform programme and why? and Is the search for a result-oriented public sector reform a myth or reality?

The study espoused that while the NPSRS is a good approach to public sector reform in Ghana because of the strong emphasis on the catalytic role of the public sector in private sector growth and development, it suffers a major hiccup due to the following three reasons: its concentration on only sixteen (16) Ministries, Departments and Agencies (MDAs), its funding from the World Bank and the limited time frame of its implementation (2018-2023). First, we opine that reform of this nature should take into consideration if not all, then majority of the MDAs instead of the selected sixteen (16). This is because the public sector MDAs are mutually interdependent hence there is always trickledown or spill over effects. Secondly, evidence abounds that whenever the World Bank funds a reform in developing countries, it comes with terms and conditions as well as strings which in most cases does not auger well for the host or recipient state (Antwi and Analoui, 2013) and thirdly, the time frame of six years (2018-2023) is problematic. The question that we want to pose is "What happens after the expiration of the reform period"?

The paper is structured into four sections. Section two is devoted to the review of the existing literature on administrative reform and empirical studies on public sector reforms in Ghana; section three examined the Ghanaian experience of public sector reform since independence. 
Section four discusses the current National Public Sector Reform Strategy (NPSRS) and its implementing tool Public Sector Reform for Result Project, its gains, and highlights key features inherent in it that makes it either a myth or reality in attaining a result-oriented public sector in Ghana. The paper ends with a conclusion and the way forward for a result-oriented public sector reform in Ghana.

\section{Administrative Reform: State of the Art Literature}

The literature on administrative reform is legion. The review will be in two parts; theoretical and empirical reviews on Ghanaian studies.

\section{Theoretical reviews}

Administrative reform has been one of the most recurrent activities of governments the world over. It has been accentuated by the severity of the problems faced by the less developed nations due to the administrative state inherited from the colonial authorities (Farazmand, 2002:1). Administrative reform as a concept in public administration lacks a universally accepted definition. Scholars and practitioners defined it variously. Caiden (1985) defined administrative reform as "the artificial inducement of administrative transformation against resistance. Montgomary (1969) expanded the definition to mean a political process that adjusts the relationship between a bureaucracy and other elements in a society or within the bureaucracy itself in order to change the behaviour of the public service. In the words of Leemans (1976), administrative reform is induced change in the machinery of government undertaken in an effort to bridge the gap between reality and desirability. On the part of Maheswari (1985), it as those deliberately planned changes in a country's public administration, which are directly conducive to the realization of objectives held dear and cherished by the society. From the above, administrative reform could be said to be intentional actions aimed at altering and transforming non-performing public bureaucracies into performing ones. It is about making the bureaucracy more productive to deliver on its mandate of providing efficient and effective public goods and services.

From the above definitions, the following features of administrative reform are gleaned:

1. It is a deliberate action to change public bureaucracies for improved performance;

2. It is synonymous to innovation, which is the injection of new ideas and new people in a new combination of tasks and relationships into the policy and administrative process;

3. Coping with the uncertainties and rapid changes taking place;

4. Administrative reform is highly political and occurs in organizational environment; and

4. Administrative reform is a continuous, never-ending process.

Caiden (1985) identified three main premises for administrative reform. These are as follows: First is the imperfectability of human institutions. In his view, perfection is beyond the reach of mankind; as a result, mankind is in constant search for improvement, hence administrative reform. Second, is the conservative or complacent nature of public organisations. In Caiden's estimation, success breeds fixation rather than flexibility. Public organisations are fixated and 
stuck to a proven formula and not prepared to try unproven ones or break new grounds. This Caiden attributed to the absence of entrepreneurial spirit in them. Third, due to the complacency, innovation tends to permeate slowly. Thus, public organisations are resistant to trying new or better ways of doing things. For innovation to be accepted, the effectiveness of new approaches will have to be demonstrated over and over with convincing evidence until every shadow of doubt is cleared.

On the approaches to administrative reform, the following have been identified in the literature: comprehensive, incremental, top-down, bottom-up, institutional and hybridity (Ohemeng and Ayee, 2016; Farazmand, 2002; Maheswari, 1985).

The following features characterize the comprehensive approach: it views all problems in a perspective; it takes into account all interrelated problems at the same time and sets in motion psychological forces both within the public administration and outside it, thereby promoting fresh and unorthodox thinking in the reform process. In spite of its robust features, it has the following setbacks:

First, no reform can cover everything that goes on in public administration; second, it runs the risk of remaining content with mere generalities without going into details. Third, its totality also calls for a huge bureaucracy with appropriate human resource to operate and perform various roles, which has financial and logistical implications. This approach is also criticized for delay in the implementation of reform because of the time taken to consider "all" factors necessary. It is instructive to note that once a reform is delayed beyond a certain period, the essence of the reform is equally undermined.

To overcome the weaknesses associated with the comprehensive approach, scholars mooted the incremental approach. Under this approach, the reformer intelligently selects targets by concentrating on points of highest pay-off, which claims many benefits including; the reformer becoming more and more trained as the work of reform proceeds. In addition, the techniques of study and investigation gets more refined as the enquiry progresses. This allows for a comprehensive reform at the end of the reform process.

The top-down approach. In this approach, reform ideas, initiatives and priorities come "from the top": thus directly from politicians to the bureaucracy, without the active involvement of the latter (Ohemeng and Ayee, 2016). In the words of Donovan (2007), it is characterized by a powerful, hierarchical state where a political elite devises policy implemented through a strict, sequential, and a stable chain of command via bureaucrats and other service providers. It emphasizes national planning, rationality, command, control, obedience and constraints and evokes notions of red tape and bureaucracy and presupposes that the success of reforms depend largely on the degree to which the reform have been developed and implemented more top-down than bottom-up (Ohemeng and Ayee, 2016; Hammerschmid et al., 2013).

The top-down approach is based on the assumption that it is necessary to adopt and implement "best practice" especially in the developing world (Ohemeng and Ayee, 2016). Easterly (2008) espoused that the top-down goes together with the view that there is one globally unique best set of institutions toward which all societies are hopefully thought to be 
developing. In public sector reforms, the approach has been presented as the classic expression in government planning (McCourt, 2012). This point was amplified by Ryan et al (2008) "senior executives or political authorities generally conceive, plan and direct implementation. Middle management is responsible for the detailed coordination and internal management of change, while non-managerial employees are vital with respect to embedding change, even though they generally have little say in the decision-making process. The approach also allows for the accountability of political authorities for the actions of public sector institutions, compel the former to make sure the latter do what is expected of them especially in democratic environment (Ohemeng and Ayee, 2016).

Despite the popularity of the approach, it has been severely criticized. Some of the criticism are discussed below.

First of all, it does not allow for the voices of the poor who are in the majority to be heard in the reform process. Thus, the bureaucrats are insulated from the citizenry. In the words of Andrew and Shah (2003), the approach encourages control in the governance process and requires role players to adhere to the process hook, line and sinker.

Second, is the problem of performance management. In performance management, both levels of management are to sit and set targets together. However, in the top-down approach, the bureaucrats do not participate in goal setting. Rather targets are set for them and the politician determines the modus operandi for assessment.

The failure of the top-down approach to appropriately lead the charge in public sector reform gave currency to the bottom-up approach in recent times in the administrative reform literature. This approach was inspired by the ideal of good governance, which means decentralisation, as well as citizen involvement in governance and public sector activities (McCourt, 2012). The bottom-up approach has three main characteristics, namely: citizen participation and engagement, voice and choice.

Citizen participation is a categorical term for citizen power. Participation is the redistribution of power that enables the have-not citizens, presently excluded from the political and economic processes, to be deliberately included in the future. It is a strategy by which the have-nots join in determining how information is shared, goals and policies are set, tax resources are allocated, programmes are operated and benefits are parceled out. In short, it is the means by which they can induce significant social reform, which enables them to share in the benefits of the affluent society (Amstein, 1969). Smith (2007), identified effectiveness in reform interventions and empowerment of the poor as beneficent outcomes of participation. Participation culminates into effectiveness because of the credibility that reforms receive due to inputs by the citizenry through their opinions and demands, which help to reduce information gaps and plug gaps in reforms. In terms of empowerment, the contribution that citizens make to the reform process (agenda setting, monitoring and evaluation etc) develops their capacity to analyse problems, reflect and take corrective actions. According to the World Bank (1997), participation provides social accountability in which the citizens and civil society organisations hold government officials to account. However, the empowerment of the poor is dependent on the right to participate (OECD, 2001). Participation ensures the 
long-term sustainability of public sector reforms, reinforces ownership of the reform, transparency and accountability (Smith, 2007).

Participation does not necessarily result in result-oriented reforms, rather the extent of participation and the information level of the citizens play a significant role in this regard. This assertion is corroborated by Fischer (2012) who argued that while citizens can participate and improve both democratic decision-making and efficient public sector service delivery, participation has to be carefully organized, facilitated and even cultivated and nurtured.

The second feature of the bottom-up is voice. Voice is the ability to speak out in public service (Hirsvhman, 1970). It also means the ability to be engaged in the development of institutional design, and to change management through soliciting feedback (McCourt, 2013; Goetz and Gaventa, 2001). Voice aids individuals, groups and civil society organisations to shape the design and delivery of public sector reforms (Smith, 2007). The voice takes the form of interest articulation, complaints, organized protests, lobbying that individuals and groups use to bring pressure to bear in the public sector reform process.

The third feature is choice. It is defined as the capacity for self-direction exercised by a self-possessed individual in personal, social, economic and political arrangements (Newman and Clarke, 2009). It comprises of giving citizens the right or the ability to choose the when, where and how of public service (Burton, 2013; Le Grand, 2007). Choice is also considered to be the right to make an application for a particular provider or package of service or whatever. Choice can take many forms in the public sector (Newman and Clarke, 2009) where it requires a special set of skills (Burton, 2013). Choice does help public sector reformers to identify the critical skills of public sector employees and focus capacity-building efforts on their development.

From the above tenets of the bottom-up approach, it can be distilled that the approach brings about innovation in the reform process through the involvement of unorthodox actors in the reform process, it results in leadership development, it also fosters both downward and upward accountability and hugely contributes to ownership of reforms by the citizens which permits reform continuity.

The greatest setback to the approach is the lack of capacity of citizens to hold public officials accountable. Serra (2008) for instance enumerated four of such capacity deficiencies. First is the inadequate information on the quality of the service provided, the standard that such services should meet and the rights of citizens as beneficiaries of public goods and services. Second, due to the high level of illiteracy coupled with elite capture, social conflict and general mistrust of formal institutions, citizens surrender their voices to the local elites who use it for their parochial interest. Third, grassroots monitoring of public officials may be subject to free riding since, on the one hand, it requires efforts by enough citizens to work; and on the other, those who decide to monitor may suffer negative consequences from corrupt officials. Finally, the absence of formal mechanisms for citizens to use in holding providers of public goods and services accountable. 


\section{MlMacrothink}

Journal of Public Administration and Governance

ISSN 2161-7104

2020, Vol. 10, No. 3

The institutional approach. This approach represents a separate group of approaches to public sector reform. It is a reaction to the inadequacies inherent in both the comprehensive versus the incremental and the top-down versus the bottom-up approaches. This approach is in currency because of the increasing interest in the new institutionalism movement in which organisational changes must take place through changes and modifications of internal organisational values and culture, as well as structure. The approach argued that public sector reforms do not emanate from political leaders or authorities or the grassroots as espoused by the top-down or bottom-up approaches respectively, rather, public sector reform focuses on the need to modify the collective values, culture and structure to make the organisation adaptive and dynamic (March and Olsen, 1984; Farazmand, 1997). This approach concentrates more on the soft aspect of organisations in the reform process. This approach is particularly important in developing countries because of the high rate of patron-client relationship that characterizes public administration. According to Woode (1997), in Ghana most public administrators perform the roles of fathers, uncles etc. Therefore, standards, ethics, values and culture are critical in reforming the public sector.

The last approach is what is known as the hybridity approach. Scholars have argued in separate studies that none of these approaches can apply in a particular situation without hindrances, hence the need to combine approaches by concentrating on the strengths of each of the approaches (Ohemeng and Ayee, 2016; Turner, 2013; Booth, 2012; McCourt, 2012, Farazmand, 2002). Though the term hybridity has been in existence in the public administration literature for a while (Skelcher, 2012; Christensen and Lāgreid, 2011; Croft et al.; 2015; Denis et al.; 2015), however, it was Ohemeng and Ayee (2016) who deployed it in the study of public sector reform. Ohemeng and Ayee (2016) conceptualized it to mean a combination of the top-down and bottom-up approaches, to extract their individual benefits. In this paper, the combination of the benefits is expanded to include the comprehensive, incremental and institutional approaches.

\section{Ghanaian empirical studies on public sector reform}

On the empirical studies on public sector reform in Ghana, Wereko (2008) espoused that various reforms have not worked because of resistance to change from both individual public servants and institutions and lack of sustained political commitment by heads of MDAs, the absence of institutionalized change management team, the lack of institutionalized reform coordinating and oversight body, financial and logistical constraints, poor process management and lack of political will. Ohemeng and Anebo (2012) found that the failure to set reform agenda since independence and the continuous disturbance of the political and administrative environment, with persistent punctuation over the years because of frequent changes of governments, led to the inability of political leaders to pursue reforms to their logical conclusion. Their study also revealed that the lack of continuity that path dependency creates significantly contributed to the drawback of the political elite to provide a strong ideological foundation for national development. In addition, the continuous reforms also resulted in the inability to create institutionalized home or oversight body to coordinate such reforms. Furthermore, public sector employees have failed to internalize the norms of public spiritedness hence they are not self-motivated to serve the public interest. 
Antwi and Analoui (2013) intimated that public sector reforms in Ghana were largely donor-funded with heavy dependence on the largesse of development partners such as the World Bank, Department for International Development etc. As a result of this reliance, the formulation and implementation of reforms were not only imposed but mostly top-down with limited consultation and participatory management thereby hindering reform sustainability.

In separate studies by Libby (1976) and Hutchful (1997), it was gleaned that public sector reforms in Ghana were driven by the continuous search for public sector organisational improvement for national development as well as the need to serve political expediency. They intimated that all the reforms assumed the top-down approach characterized by reform initiative, planning and development emanating from the office of the Head of State be they civilian or military with assistance from bureaucrats from international organisations who were in most cases the financiers.

Ohemeng and Ayee (2016) asserted that despite the numerous reforms undertaken in Ghana since independence, the public sector especially the civil service continues to underperform especially in policy formulation and implementation. They also espoused that the National Democratic Congress government's reform called the new approach in public sector aimed at moving the public sector away from the business-as-usual syndrome also fell victim to the exclusively top-down and bottom-up syndrome to the neglect of the hybrid approach which is deemed as the game changer.

This study makes a modest contribution to the debate on public sector reforms in Ghana by examining the New Patriotic Party's National Public Sector Reform Strategy (NPSRS), 2018-2023 as to whether public sector reform in Ghana is a myth or reality.

\section{Public Sector Reforms in Ghana: A Checkered History}

This section of the article is devoted to the trajectory of public sector reforms in Ghana since independence. Since sufficient ink has been poured on the area by leading scholars, the section will highlight the significant features, ideology underpinning the reforms, the gains and reasons for failure (Ohemeng and Ayee. 2016; Ayee, 2013; Antwi and Analoui, 2013; Ohemeng and Anebo, 2012; Wereko, 2008, Ayee, 2001).

The search for a result-oriented public sector have compelled both civilian and military governments that ruled Ghana since independence in 1957 to introduced public sector reforms aimed at re-orienting the sector to meet national developmental goals and to serve expedient political objectives (Ohemeng and Ayee, 2016; Ayee, 2013; Ohemeng and Anebo, 2012). Most of these reforms failed to achieve the predetermined objectives because they were top-down in nature with little input from the bureaucrats, the objectives were over ambitious, limited time frame, directly transplanted into Ghana without considering environmental factors and funding from development partners with conditionalities and strings attached.

\section{The Convention Peoples' Party era public sector reform (1957-1966)}

The British colonial masters handed over to Kwame Nkrumah in 1957 a public sector, which 
predominantly had the top-hierarchy occupied by the British with their Ghanaian counterparts at the bottom with no effort to build the capacity of the Ghanaians or orient them towards effective service delivery (Ohemeng and Anebo, 2012:166). To address this, the Lidbury Commission was established to assess how the public sector can be restructured for improved public service delivery under the 1951 self-government constitution (Wereko, 2008:18). This resulted in the adoption of democratic-centralism with central planning and the president playing a significant role (Omaboe, 1966). This culminated into massive centralization of administrative authority and excessive politicization of the public sector (Muwanga-Barlow, 1978; Nti, 1975). The reform was underpinned by the socialist ideology because of Nkrumah's socialist inclination. This reform was characterized by three main features, namely:

1. The Africanisation of the public sector. This was targeted at removing all expatriates in the bureaucracy occupying policy advising and formulation positions to make way for their Ghanaian counterparts. In the words of Nkrumah, independence means the African was capable of managing her own affairs including managing the public sector.

2. The introduction of state-owned enterprises (SOEs). This was done through the establishment of several public institutions such as Community Development Departments and regional offices of the various ministries to assist in national development. To deepen commitment to national development, the government created specialized secretariats, made up of the State Planning Commission, the State Control Commission, the Productivity Centre, the Water Resources and Power Secretariat, the Volta River Authority, the State Enterprises Commission and the Civil Service Commission which were all outside the regular public services but directly under the office of the president to underscore the centralisation agenda (Ohemeng and Anebo, 2012:167; Kraus, 1971).

3. The creation of parallel structures in the administrative fibre of the state. The establishment of institutions under the office of the president complicated the administration of the state and weakened the ability of the authorities to coordinate national development due to some of these state institutions becoming silos, resulting in coordination failures which ultimately hampered socio-political and economic growth (Ohemeng and Ayee, 2016:287).

\section{Public sector reform under the National Liberation Council (1967-1972)}

The National Liberation Council (NLC) government that overthrew the CPP government in 1966 through a military coup was not satisfied with the structure and performance of the public sector hence they established the Mills-Odoi Commission in 1967 to examine the civil service and to make recommendations for its reform. The Commission made recommendations aimed at the improvement and efficient functioning of the government machinery to enhance national development (Ohemeng and Anebo, 2012:167). These recommendations brought about the merger of ministries and secretariats from 31 to 17 and 23 to 8 respectively and decentralisation of some government functions (Ohemeng and Ayee, 2016:287; Ohemeng and Anebo, 2012:167; Nti, 1975). The ideological underpinning of the reform under the NLC was market-oriented (Ohemeng and Anebo, 2012:167). 
Public sector reform under the Progress Party (1969 - 1972)

The Progress Party (PP) came to power in 1969 after winning the general elections that year. The PP government decided to continue with the reform started by the NLC because it believed in the market-oriented philosophy of the NLC, however, it did not embark on any major public sector reform initiative (Ohemeng and Anebo, 2012:167). The PP government had the responsibility of implementing the recommendations of the Mills-Odio Commission's report especially the decentralisation of personnel to regional and district offices of the civil service. Although the government accepted the wisdom of decentralisation, it moved "in the opposite direction with its assignment of personnel control to ministers ... and failed to consider delegating some appointment powers to heads of departments" as pointed out by Nti (1975:173). The government also tightened central control of personnel and went on to appoint Regional Chief Executives and Chairmen of District Councils (Ohemeng and Anebo, 2012:167). The use of decentralisation as a tool to reform the Civil Service under the NLC and PP governments was seen as a double edged sword because, whereas the NLC government saw it as a means to improve the operational efficiency, the PP was hesitant to implement it because of the fear that it would "result in a politically uncontrollable Civil Service" (Muwanga-Barlow, 1978:101). In the words of Ohemeng and Anebo (2012:167), the PP government's attempt to reform the administrative state was half-hearted and quite disappointing and made nonsense of the initial efforts at restructuring public sector institutions and even expanding them.

\section{Public sector reform under the National Redemption Council (1972-1978)}

Ocquaye (1980) argued that the aim of the National Redemption Council (NRC) was to reverse a number of things undertaken by the PP and to promote domestic development. In this regard, there was a return to the socialist agenda (Ohemeng and Anebo, 2012:168). In the government's bid to initiate reform, it inaugurated the Okoh Commission in 1976 to among other things investigate the organisation and structure of the Civil Service and its methods of operation, enquire into other things related to the Civil Service and report the findings to the government. The Commission made two main recommendations:

1. The reorganization of the Civil Service to focus on sector policy planning, coordination, monitoring and evaluation activities of government while divesting itself of implementation

2. Like the Mills-Odoi Commission, it recommended the decentralisation of central agencies so that these agencies would concentrate on implementing government policies and report to their political heads at the regional level.

However, these recommendations did not see the light of day because the regime was preoccupied with legitimizing itself (Ohemeng and Ayee, 2016:288; Ohemeng and Anebo, 2012:168; Wereko, 2008; Ayee, 1991).

The Armed Forces Revolutionary Council (AFRC) which overthrew the Supreme Military Council (SMC II) on June 4, 1979 did not initiate any public sector reform because it's stay in power was brief (113 days) and intimated that it came to power to clear the mess created by the previous regimes (Okyere, 2000:246). True to its words, national general elections 
were held and the People's National Party (PNP) led by Dr. Hilla Limann won after a runoff held on July 9, 1979. On September 24, 1979, the AFRC handed over power to the PNP. The PNP government could not introduce any public sector reform because of the truncation in power by a coup d'état on December 31, 1981 making the government to rule for one year three months.

\section{Public sector reform under the Provisional National Defence Council (PNDC) (1981-1992)}

By the early 1980s, it became abundantly clear that successive efforts aimed it injecting efficiency and effectiveness into the public administration system have proved futile hence, Nti (1980:20) described it as "a moribund paper-pushing institution". In a bid to salvage the situation, the PNDC in May, 1982, instituted the Kaku Kyiamah Committee to advise it on how to restructure the bureaucracy. The Committee made four main recommendations to the government as follows

1. The Civil Service should restrict itself to the formulation of policies;

2. The Civil Service should restrict itself to the provision of administrative support to political heads;

3. The Civil Service should restrict itself to coordinating and monitoring of programmes and activities within the ministerial sector and

4. The Civil Service should restrict itself to the conduct of inter-ministerial relationships.

These recommendations were considered as the magic wand to revolutionize the Civil Service (Ohemeng and Ayee, 2016:288; Ohemeng and Anebo, 2012:168; Ayee, 1993). According to Ohemeng and Ayee (2016:288), the government could not implement the recommendations because it became extremely concerned with making cosmetic improvements to the dire economic conditions in the country at the time.

In 1987, after stabilizing the economy and reversing the downward trend, the government initiated the Civil Service Reform Programme (CSRP) to address the weaknesses identified in the civil service under the structural adjustment programme. The reform was to reinvigorate the service to enable it actively contribute to the success of the Structural Adjustment Programme (SAP) (Ohemeng and Anebo, 2012:169; Hutchful, 2002; Larbi, 1995). The reform made a gain by shrinking the size of the civil service from 140,000 to 93,000 , it however failed to alter the performance culture of the civil service because it neglected the human and structural capacities such as training in policy implementation, ethics etc (Ohemeng and Ayee, 2016:288; Antwi and Analoui, 2013:61; Ohemeng and Anebo, 2012:169; Larbi, 1995). It is instructive to note that all these reforms under the PNDC were donor funded, market-oriented in philosophy characterized by cost reduction and cost containment (Ayee, 2017:46).

\section{Public sector reform under the National Democratic Congress (NDC), 1993-2000}

On return to constitutional rule and democratic governance in 1993, the public sector was still operating moribund hence, the search for a new approach to breath new breathe into it. In 
response, the civilian NDC government (1993-2000), passed the Civil Service Law 1993 (Act 327) and initiated the Civil Service Performance Improvement Programme (CSPIP) with the view to addressing the structural and performance culture defects that had plagued the service (Ohemeng and Ayee, 2016:288; Antwi et al., 2008; Wereko, 2008). This reform was driven by the market-oriented ideology and had the National Institutional Renewal Programmes (NIRP) as the institutional home for all the reforms. These reform had eight key features (Ohemeng and Ayee, 2016:289; Ohemeng and Anebo, 2012:169)

1. Improving the overall performance of the civil service in service delivery,

2. Developing a culture of results and performance orientation,

3. Providing value for money in all endeavours,

4. Achieving a higher level of efficiency through cost-effective methods

5. Innovation

6. Market or Customer sensitivity

7. Transparency, accountability and enhancing the culture of good governance.

8. It had a performance management system that enabled the government to hold the public service accountable for policy development and service delivery.

Though the reform made some gains (Ayee, 2001), the service was still not as expected after the reform. For instance, Werlin (2003:334) espoused that "efforts during the 1990s to improve the functioning of the civil service proved unsuccessful, with the management of financial resources continuing to be weak in monitoring actual expenditures, auditing and inconsistently applying regulations. All of the institutions of government were affected by pervasive clientelism and personalism (thereby undermining political software) that inevitably stoked the fires of corruption".

\section{Public sector reform under the New Patriotic Party (NPP) (2001-2008)}

With this failure, the NPP government, which ruled the country from 2001 to 2008 continued unabatedly to search for a result-proof public sector reform programme. Following the recommendation of the J.H. Mensah Advisory Committee, the Public Sector Reform Programme (PSRP) of 2003 with the Ministry of Public Sector Reform as the institutional home was berthed and launched. This reform was market-oriented in approach; however, it was a complete departure from earlier ones in that it focused on service delivery improvement as against economic and capacity development reforms (Ayee, 2017:47). The reform had three key features (Ohemeng and Ayee, 2016:289; Ayee, 2017:47 Ohemeng and Anebo, 2012: 170) namely:

1. To revitalize existing public sector reform activities and to facilitate and coordinate future ones

2. The Citizen Charter aimed at building the capacity of the civil service for service delivery and accountability to service recipients. 
3. Performance management was inbuilt just as its predecessor reform.

Despite the commitment to make the reform work, by 2008, these efforts and initiatives had proved either stillborn (in the case of the new performance management regime) or in the case of the Citizen Charter, implementation had hit some major roadblocks (Ohemeng and Ayee, 2016:289; Ohemeng and Anebo, 2012:170). Before any remedial action to redeem the reform from the doldrums, the NPP had lost political power to the NDC in the 2008 general elections.

\section{Public sector reform under the National Democratic Congress (NDC) (2009 - 2016)}

The NDC governed the country from 2009 to 2016. In 2010, it introduced the "new approach" to public sector reform. The fundamental objective of the reform was the transformation of the public sector processes in order to link public administration capability to broader national development based on the Better Ghana Agenda. The reform had the following features: first, it was sector driven and put responsibility at the doorstep of sector ministers in that they (sector ministers) assumed primary responsibility for utilizing resources available to reform their respective ministries. Second, the reform was underpinned by the fact that the President assisted by Cabinet directed programmes, projects and activities of the reform to tackle developmental challenges. Third, the "new approach" requested sector ministers to identify reform needed to support their sector programmes and job creation proposal. The identified needs were then submitted to Cabinet for approval and implementation at the sector level (Ohemeng and Ayee, 2016:250; Ayee, 2017:50). Fourth, the Public Sector Reform Secretariat (PSRS) under the Office of the President with a minister of state was the institutional home for the reform and assisted MDAs in accessing and using resources to achieve the objective of the projects. Fifth, the reform services were to be tied directly to productivity, including pay reforms and training. Sixth, like its predecessor, there was a performance management system, which comprised of the Office of the President, ministers and chief directors using the balance scorecard system. Seventh, ministers were responsible for reform spending, while further funding to MDAs was channelled through the PSRS (Ohemeng and Ayee, 2016:290; GoG, 2010). Factors such as narrow focus on political commitment, limited capability building, exclusion of frontline bureaucrats, and lack of synergy between government, the private-for-profit and nongovernmental sectors were identified as setbacks to the success of the "new approach" (Ohemeng and Ayee, 2016:292-293). This reform as usual did not live beyond the life span of the government that formulated it. The NDC lost political power to the NPP in the 2016 general elections, consequently, the search for a result-oriented public sector reform continued. The search led to the National Public Sector Reform Strategy (NPSRS) 2018-2023. This will engage our attention.

\section{The National Public Sector Reform Strategy (NPSRS) 2018-2023}

The NPP won the 2016 general elections and formed government in January, 2017. According to the NPP, Ghana has had several reforms, however, only few of them were supply driven, not informed by a comprehensive national strategy, not effectively coordinated by a central body in a visible manner, and had no linkages to each other. To the NPP 
government, the reforms have made modest improvements; however, they were unable to achieve the desired transformation in the performance of the public sector. In the words of the office of the Senior Minister, "till date, the public sector has not been able to effectively contribute the needed support to stimulate private sector growth and development for wealth and job creation" (www.gog/osm.gh).

To arrest the situation, the President on $8^{\text {th }}$ August, 2018, launched a new public sector reform called the National Public Sector Reform Strategy (NPSRS), 2018-2023 on the theme "Delivering for Citizens and the Private Sector. The reform has three beneficent elements inherent in it;

1. The catalytic role of the public sector in private sector growth and development,

2. A blend of the public and private sector to boost the government's ability to generate more tax revenue and

3. A well-functioning public sector with a business-friendly mind-set to foster an enabling environment attractive to and supportive of, both domestic and external investment for growth in government's revenue (www.gov/osm/gh).

For effective reform implementation, a Public Sector Reform for Results Project (PSRRP) was developed. The PSRRP is geared towards improving the efficiency and accountability in the delivery of selected services by selected entities. The PSRRP was a US\$35 million credit from The World Bank and was approved by the Board of Executive Directors on $23^{\text {rd }}$ October, 2018 and was signed on $12^{\text {th }}$ November, 2018 (www.gov/osm.gh).

Specifically, the PSRRP aims to help sixteen (16) selected agencies improve efficiency and accountability in delivery of key public services to citizens and firms, such as issuance and renewal of passports, vehicle registration and environmental permits, and registration of births and deaths. To incentivize these sixteen entities to improve, technical assistance and rewards are made available to those entities to achieve the set targets and improve public accountability through disbursement-linked indicators (DLIs).

The project has four (4) components with activities to spearhead the achievement of project objectives.

Component 1. Strengthening organizational performance: This component provides support to the Office of the Head of Civil Service (OHCS) and Public Services Commission (PSC) to strengthen their capacity and organizational management and those of Selected Entities (SE) and other institutions under their oversight. It strengthens the capacity of the Commission for Human Rights and Administrative Justice's (CHRAJ's) grievance redress and complaints handling of fairness in the delivery of administrative services.

Component 2. Improving efficiency, accountability and citizen engagement in the delivery of selected services: This component assists the SEs to improve their efficiency and accountability in the delivery of selected services. The selected entities include Driver and Vehicle Licensing Authority (DVLA), Ministry of Trade and Industry (MoTI), Birth and Death Registry (BDR), Ministry of Local Government and Rural Development (MLGRD), 
Environmental Protection Agency (EPA), Ministry of Environment, Science, Technology and Industry (MESTI), Passport Office (PO), Ministry of Foreign Affairs and Regional Integration (MFARI), Ghana Immigration Service (GIS), Ministry of Interior (MoI). It also aids National Information Technology Authority (NITA) to provide information and communication technology (ICT) core services, other relevant ICT services and related technical support and training to the SEs. In addition, the component sought to support NITA to implement Service Level Agreements (SLAs) with each SE to provide the specified services according to mutually agreed standards. This component would also support the implementation of Government's NPSRS (2018-2023) relating to improving efficiency, accountability and citizen engagement in the delivery of services by SEs except for OHCS, PSC and CHRAJ.

Component 3: Monitoring and Evaluation: This component has two sub-components. These are i. Strengthening the capacity of the Ministry of Monitoring and Evaluation (MoME), MDAs and MMDAs through inter alia:

a) Preparing and implementing M\&E policy and performance measurement; and monitoring implementation of the GRF for priority programmes;

b) Developing and monitoring real-time performance for MDAs and MMDAs; and

c) Strengthening $M \& E$ capacity.

2. Carrying out activities for enabling stakeholders to interact with citizens and civil society, conducting annual citizen assessment surveys and publishing the results.

Component 4. Project management, coordination and public reporting: Carrying out activities to strengthen the Government's capacity for the project management and coordination including monitoring and evaluation, fiduciary aspects, recruitment of the Independent Verification Agent (IVA) to verify the attainment of the Disbursement Linked Indicators (DLIs), carrying out public outreach on the project and the NPSRS, generating feedback from citizens and firms on the selected services; and instituting a Project-level grievance redress and complaints handling mechanism.

The participating MDAs are in three categories. These are frontline service delivery agencies, parent ministries and central management agencies.

Table showing list of participating MDAs in the reform

\begin{tabular}{|c|c|c|}
\hline elivery agencies & istries & Central management agencies \\
\hline $\begin{array}{l}\text { 1. Driver and Vehicle } \\
\text { Licensing Authority (DVLA) } \\
\text { 2. Passport Office (PO) } \\
\text { 3. Ghana Immigration } \\
\text { Service (GIS) } \\
\text { 4. Environmental Protection } \\
\text { Agency (EPA) }\end{array}$ & $\begin{array}{l}\text { 1. Ministry of } \\
\text { Monitoring and Evaluation } \\
\text { 2. Ministry of Local } \\
\text { Government and Rural } \\
\text { Development } \\
\text { 3. Ministry of Foreign } \\
\text { Affairs and } \quad \text { Regional }\end{array}$ & $\begin{array}{l}\text { 1. Public Services } \\
\text { Commission (PSC) } \\
\text { 2. Office of the Head of the } \\
\text { Civil Service (OHCS)/ Public } 3 . \\
\text { Records and Archives Administration } \\
\text { Department (PRAAD) } \\
\text { 4. Commission on Human }\end{array}$ \\
\hline
\end{tabular}




\section{Macrothink}

Journal of Public Administration and Governance

ISSN 2161-7104

2020, Vol. 10, No. 3

\begin{tabular}{|c|c|c|}
\hline $\begin{array}{l}\text { 5. Births and Deaths Registry } \\
\text { (BDR) }\end{array}$ & $\begin{array}{l}\text { Integration } \\
4 . \quad \text { Ministry of } \\
\text { Environment, Science, } \\
\text { Technology and Innovation } \\
\text { 5. Ministry of the } \\
\text { Interior } \\
\text { Ministry of Transport }\end{array}$ & $\begin{array}{l}\text { Rights and Administrative Justice } \\
\text { (CHRAJ) } \\
5 . \quad \text { National Information } \\
\text { Technology Agency (NITA) }\end{array}$ \\
\hline
\end{tabular}

\section{Source: Office of the Senior Minister, 2019}

Comparatively, this is the only public sector reform since independence aimed at using the public sector to catapult the growth of the private sector. This reform is market-oriented in nature, donor-funded, time bound (2018-2023), top-down in nature and did not cover all public sector organisations. It had the Office of the Senior Minister (OSM) as the institutional home coordinating the 16 MDAs for result.

\section{Public sector reform in Ghana, myth or reality?}

With the array of reforms since independence, can it be argued that Ghana will have a resultoriented public sector? This section of the article is committed to answering this question by analyzing how the reforms emerged and implemented and how the intricacies inherent in them either accounted for the reforms being a myth or reality.

The reform has made some gains in its brief period of implementation which includes: the timely issuance of biometric driver's license and birth certificates and the online application for passport.

In the midst of these gains, it is bedeviled with the following, which makes the search for a result-oriented public sector more of a myth than a reality.

1. The reform emerged from the manifestos of the political parties. Manifestos set the agenda for what a political party will do when voted into power. The public sector reforms implemented especially during constitutional rule in Ghana emanated from the manifestos of the political parties. For instance, the 2008 Manifesto of the NDC indicated, "in the first term, the NDC government will ensure that the civil service gets back on track with reforms that will enable it to play its pivotal role in the system of governance". It further stated that "the NDC government will ensure a civil service leadership characterized by competence and provide remuneration structure that will make civil servants more effective and efficient" This will help attract and retain the requisite human resource needed for economic growth and development (Ohemeng and Ayee, 2016:289). The NPP on its part was not clear on its public sector reform in its 2016 Manifesto, however, there were implicit statements pointing to reforming the DVLA, the Passport Office, Ghana Immigration Service for the purposes of economic growth, job creation and positioning the private sector to make the needed contribution to national development (NPP, 2016). The implementation of manifestos by political parties in government confirms the words of Mahama (2013:42), that because 
politicians always wants to have the support of the grassroots, they implement reforms in line with their party manifesto. The emergence of reforms from party manifestos give rise to the narrow focus on political commitment as espoused by Ohemeng and Ayee (2016:292) "the reform largely emanated from the manifesto of the NDC government, and was therefore politically motivated, ignoring the views of other stakeholders. This culminates into excessive partisanship in the implementation of public sector reforms.

2. The reforms were donor driven. Most reforms in Ghana were sponsored by the World Bank and the International Monetary Fund including the current PSRRP under the NPP, which is costing US\$35 million. This makes the reforms to be top-down without local ownership and comes with terms and conditions. As discovered by Antwi and Analoui (2013:61), planning and implementation processes of donor-funded reforms were not only imposed top-down but had limited consultation and participatory management principles problems. The other challenge with donor-funded reforms is that they were time bound. Reforms largely should not be time bound; they must be continuous in order to reap the anticipated benefits in totality. The paper poses two questions. These are: first what happens to public sector reforms after 2023, which is the time span for the current reform, and second, what happens when the US\$35 million assigned to the reform is exhausted?

3. The reform was focused on only 16 selected MDAs meanwhile Ghana has more than 16 MDAs. In the words of Ayee (2019), Ghana's public sector is wide, vast and amorphous. Public sector institutions operate on the principle of interdependence and not as silos; therefore, what happens in one affects the other. In other words, sequential and reciprocal consequences and spill over effects characterize them. The selection of only 16 MDAs will not bring about the needed result.

4. The National Public Sector Reform Strategy and its Public Sector Reform for Results assumed the top-down approach with its associated weaknesses. From the official document of the Government of Ghana, the Board of Executive Directors of the World Bank approved the reform. This raises questions of sufficient stakeholder engagement.

5. Preliminary assessment of the National Public Sector Reform Strategy (NPSRS) shows that some gains have been made; however, it is also plagued with challenges. For instance, the Birth and Death Registry could not issue birth certificates for close to six months because of machine breakdown, both the Passport Office and Driver and Vehicle Licensing Authority are still battling with the activities of intermediaries (goro boys) in their operations. Excessive bureaucracy in getting permit from the EPA and other regulatory authorities thereby encouraging illegal and unauthorized structures and business operations.

\section{The Way Forward}

For reforms to yield the desired results, the following conditions for success are offered:

1. Commitment to the Chapter 6 of the 1992 Republican Constitution of Ghana. This Chapter deals with the Directive Principles of State Policy. Commitment to this constitutional provision will ensure continuity of reforms as envisaged in Article 35(7) "As far as practicable, a government shall continue and execute projects and programmes commenced 
by the previous Government". Commitment to the Chapter 6 has two key dividends. First, it will aid in either minimizing or neutralizing the excessive partisanship and politicking of reforms and second, it will bring about broader stakeholder engagement in public sector reforms where identifiable and interest groups such as bureaucrats, NGOs, CSOs, etc will all be engaged in the reform process since it is about the national interest and not a political party's interest.

2. It is true that Ghana currently does not have the required financial mussels to totally fund its reforms. The article, however, recommends that the national interest should not be sacrificed on the altar of donor funding of reforms. It would be recalled that approximately 47,000 public servants lost their jobs in the 1990s during the implementation of the Civil Service Performance Improvement Programme, national assets were privatized as conditions for some reform funding etc. The end result of every reform is to better the lot of the citizenry, leaders should be guided by this principle of protecting the populace.

3. Permanent institutional home for public sector reforms. The article recommends either the Public Services Commission or the Office of the Head of the Civil Service instead of the current "musical chairs" where every government decides to create its own institutional home. The PSC or OHCS is recommended because they are permanent bodies, which survive regime changes.

4. Public sector reform in Ghana should adopt the hybrid approach, which encompasses the comprehensive, incremental, top-down, bottom-up and institutional approaches. The adoption of this approach will help in overcoming the weaknesses that have characterized reforms in Ghana, which have predominantly been top-down.

\section{Conclusion}

The paper sought to examine whether the search for a result-oriented public sector reforms in Ghana is a myth or reality. In achieving this, the paper discussed the trajectory of public sector reforms in Ghana from independence and realized that reforms in Ghana have had a checkered history hence the continuous search for the ideal reform. The paper gleaned that the failure of successive reforms compelled the NPP government to adopt the NPSRS with PSRRP as the main implementing tool to make the public sector serve as a catalyst for private sector growth and development for wealth and job creation. It was discovered that the reform in its brief period of implementation has made some gains, however, issues such as donor funding, the time bound of the reform and the selection of only 16 MDAs out of the lot will water down the effectiveness of the reform in making the public sector result-oriented. Based on this, the article concludes that the search for a result-oriented public sector reform in Ghana is a myth and not a reality.

\section{References}

Amstein, S. R. (1969). A ladder of citizen participation, Journal of the American Institute of Planners, 35(4), 216-224. https://doi.org/10.1080/01944366908977225

Andrews, M., \& Shah, A. (2003). "Citizen-centered Governance: A new approach to public 
sector reform", in A. Shah (Ed.), Bringing Civility in Governance, Vol. 3 of Handbook on Public Sector Performance Reviews. Washington, DC: World Bank.

Antwi, K. B., \& Analoui, F. (2013). "Challenges of making donor-driven public sector reform in sub-Saharan Africa sustainable: Some experiences from Ghana", in Rees, C.J. \& Hossain, F. (Eds.), Public sector reform in developing and transitional countries: Decentralisation and local governance.

Antwi, K. B., Analoui, F., \& Agyekum, N. D. (2008) Public Sector Reform in Sub- Saharan Africa: What can be learnt from the civil service performance improvement programme in Ghana?, Public Administration and Development, 28(4), 253-64. https://doi.org/10.1002/pad.503

Ayee, J. R. A. (1991). Civil Service Reform Under the Provisional National Defence Council (PNDC) of Ghana, Journal of Management Studies, 7, 1-10.

Ayee, J. R. A. (2001). Civil Service Reform in Ghana: A case study of contemporary problems in reform in Africa, African Journal of Political Science, 6(1), 1-41. https://doi.org/10.4314/ajps.v6i1.27319

Ayee, J. R. A. (2017). "Leadership and the Ghanaian State today: Reflections and Perspectives", Accra: Ghana Academy of Arts and Sciences.

Ayee, J. R. A. (2019). "Six decades of the public sector in Ghana" in Politics, Governance and Development in Ghana, Ayee, J.R.A. (Ed.), London: Lexington Books.

Booth, D. (2012) Working with the grain and swimming against the tide, Public Management Review, 14(2), 163-80. https://doi.org/10.1080/14719037.2012.657959

Burton, M. (2013). The Politics of Public Sector Reform: From Thatcher to the coalition. Basingstoke: Palgrave Macmillan. https://doi.org/10.1057/9781137316240

Caiden, G. E. (1985). Administrative reform-A global perspective, Indian Journal of Public Administration, XXXI(3), 459-471. https://doi.org/10.1177/0019556119850301

Christensen, T., \& Lægreid, P. (2007). The Whole-of-government Approach to Public Sector Reform, Public Administration Review, 67(6), 1059-66. https://doi.org/10.1111/j.1540-6210.2007.00797.x

Croft, C., Currie, G., \& Lockett, A. (2015). Broken "two-way windows? An exploration of professional hybrids, Public Administration, 93(2), 380-94. https://doi.org/10.1111/padm.12115

Denis, J. L., Ferlie, E., \& Van Gestel, N. (2015). Understanding Hybridity in Public Organisations, Public Administration, 93(2), 273-89. https://doi.org/10.1111/padm.12175

Donovan, C. (2007). Top-down Approach, in Bevir, M. (Ed.), Encyclopedia of Governance. London: Sage.

Easterly, W. (2008). Institutions: Top down or bottom up?, American Economic Review: 
Papers \& Proceedings, 98(2), 95-99. https://doi.org/10.1257/aer.98.2.95

Farazmand, A. (1997). Ethics, professionalism and the image of the public service. Special publication of the United Nations, Paper presented at the World Conference of experts on Public Administration and Finance, New York:UN/ST/SG/AC.6/1997/L.3.

Farazmand, A. (2002). Administrative reform in developing nations, New York: Praeger.

Fischer, F. (2012). Participatory governance: From theory to practice in Levi-Faur (Ed.), Oxford Handbook of governance, Oxford: Oxford University Press. https://doi.org/10.1093/oxfordhb/9780199560530.013.0032

Ghana, Republic of (1992). Constitution of the Republic of Ghana, Accra: Ghana Publishing Corporation.

Goetz, A. M., \& Gaventa, J. (2001). Bringing Citizen Voice and Client Focus into Service Delivery. IDS Working Paper 138. Brighton: Institute of Development Studies, University of Sussex.

Hirschman, A. O. (1970) Exit, Voice, and Loyalty: Responses to decline in firms, organizations, and states. Cambridge, MA: Harvard University Press.

Hutchful, E. (1997). The Institutional and Political Framework of Macroeconomic Management in Ghana. Geneva: United Nations Research Institute for Social Development (UNRISD).

Hutchful, E. (2002). Ghana's adjustment experience: The paradox of reform, Oxford: James Currey.

Kraus, J. (1971). Political change, conflict and development, in Foster P. \& Zolbery, A.R. (Eds.), Ghana and the Ivory Coast: Perspectives on modernization, Chicago: The University of Chicago Press.

Larbi, G. A. (1995). Implications and Impact of Structural Adjustment on the Civil Service: The case of Ghana. The Role of Government in Adjusting Economies Paper 2. Birmingham: Development Administration Group, University of Birmingham.

Leemans, A. F. (1976). A conceptual framework for the study of reform of central government, Leemans, A.F. (Ed.), The management of change in government, The Hague: Martinus Nijhoff. https://doi.org/10.1007/978-94-010-1383-3_2

Le Grand, J. (2007). Other Invisible Hand: Delivering public services through choice and competition. Princeton, NJ: Princeton University Press.

Libby, R. T. (1976). External Co-optation of a Less Developed Country's Policy Making: The case of Ghana, 1969-1972, World Politics, 1(10), 67-89. https://doi.org/10.2307/2010047

Mahama, C. (2013). Politics of decentralisation reforms in Ghana: The experience of Northern Ghana, Kumasi: University Press.

Maheshwari, S. (1985). Administrative reform: Towards theory building, Indian Journal of 
Public Administration, XXXI(3), 487-498. https://doi.org/10.1177/0019556119850303

March, J. G., \& Olsen, J. P. (1984). The new-institutionalism: Organizational factors in political life, American Political Science Review, 78, 734-749. https://doi.org/10.2307/1961840

McCourt, W. (2002). New Public Management in Developing Countries', in K. McLaughlin, S. P. Osborne and E. Ferlie (eds), New Public Management: Current Trends and Future Prospects. London: Routledge.

Montgomery, J. (1969). Source of bureaucratic reform: A typology of purpose and politics, in Braibanti, R. (Ed.), Political and administrative development, Durham: Duke University Press.

Muwanga-Barlow, C. H. (1978). The Development of Administrative Sciences in English-speaking Africa, International Review of Administrative Sciences, 44(1), 93-105. https://doi.org/10.1177/002085237804400108

Newman, J., \& Clarke, J. (2009) Public, Politics, and Power: Remaking the public in public services. London: Sage. https://doi.org/10.4135/9781446216651

Nti, J. (1975). 'Ghana's Experience in Administrative Reform of the Central Bureaucracy', in Rweyemamu, A.H. \& Hyden, G. (eds), A Decade of Public Administration in Africa. Nairobi: East African Literature Bureau.

Nti, J. (1980). Civil Service: Its appraisal and its prospects, Accra: Ghana Universities Press.

Ocquaye, M. (1980). Politics in Ghana, 1972-1979, Accra: Tonado.

OECD. (2011) Public Servants as Partners for Growth: Toward a stronger, leaner and more equitable workforce. Paris: Organisation of Economic Co-operation and Development.

Ohemeng, F. L. K., \& Anebo, F. K. (2012). The Politics of Administrative Reforms in Ghana: Perspectives from path dependency and punctuated equilibrium theories, International Journal of Public Administration, 35(3), 167-176. https://doi.org/10.1080/01900692.2011.635470

Ohemeng, F. L. K., \& Ayee, J. R. A. (2016). The New Approach" to Public Sector Reforms in Ghana: A Case of Politics as usual or a Genuine Attempt at Reform, Development Policy Review, 34(2), 277-300. https://doi.org/10.1111/dpr.12150

Okyere, V. N. (2000). Ghana: A historical survey, Accra: Vinojab Publications.

Quartey, G. A. (2007). The Ghana civil service: Engine for development or impediment? Ghana speaks lecture/seminar, Series Number 1, Accra, Ghana: Institute for Democratic Governance.

Ryan, N., Williams, T., Charles, M., \& Waterhouse, J. (2008) 'Top-down Organizational Change in an Australian Government Agency', International Journal of Public Sector Management, 21(1), 26-44. https://doi.org/10.1108/09513550810846096 
Serra, D. (2008). Combining Top-down and Bottom-up Accountability: Evidence from bribery experiment. CSAE WPS 25. Oxford: Centre for the Study of African Economies (CSAE), University of Oxford.

Skelcher, C. (2012). What Do We Mean When We Talk About 'Hybrids' and 'Hybridity' in Public Management and Governance? Working Paper. Birmingham: Institute of Local Government Studies, University of Birmingham.

Smith, B. C. (2007). Good Governance and Development, New York: Palgrave. https://doi.org/10.1007/978-1-137-06218-5

Turner, M. (2013) Summary Report of the Public Sector Governance Reform Evaluation. London: Department for International Development.

Werlin, H. H. (2003). 'Poor Nations, Rich Nations: A theory of governance', Public Administration Review, 63(3), 329-42. https://doi.org/10.1111/1540-6210.00293

Wereko, T. B. (2008). Public Sector Reforms in Ghana: In search of effective service delivery, Seminar Series Number 1. Accra: Institute for Democratic Governance (IDEG).

Woode, S. N. (1997). Values, standards and practices in Ghanaian organisational life, Accra: Asempa Publishers.

\section{Copyright Disclaimer}

Copyright for this article is retained by the author(s), with first publication rights granted to the journal.

This is an open-access article distributed under the terms and conditions of the Creative Commons Attribution license (http://creativecommons.org/licenses/by/4.0/). 